\title{
Phytoplankton Communities in a Coastal Site of Natural Reserve "Lake of Tarsia-Mouth of River Crati"-Northern Ionian Sea, Calabria (Italy)
}

\author{
Alessandra Giulia Chiara Marincola, Luisa Ruffolo, Davide Cozza, Radiana Cozza \\ Department of Biology, Ecology and Earth Science, University of Calabria, Arcavacata di Rende, Italy \\ Email: radiana.cozza@unical.it
}

Received May 11, 2013; revised June 13, 2013; accepted July 12, 2013

Copyright (C) 2013 Alessandra Giulia Chiara Marincola et al. This is an open access article distributed under the Creative Commons Attribution License, which permits unrestricted use, distribution, and reproduction in any medium, provided the original work is properly cited.

\begin{abstract}
Our work was aimed to study the phytoplankton communities in two coastal sites placed in Natural Reserve "Lake of Tarsia-Mouth of river Crati" in Northern Ionian Sea-Calabria (Italy). This zone represents a wetland area of high natural interest populated by different organisms (animals and plants) living in a transitional ecosystem characterized by a great biodiversity. The sampling was performed in two different seasonal periods (summer and autumn 2012) and in two different sites (marine site vs fluvial one). Different algal genera/species were recognized and analyzed by Utermöhl inverted microscope method and also qualitative and quantitative measures of biomass were performed. The results showed that the dominant group was the Diatoms with exclusive species in such periods in both the sampling sites; we also observed the presence of genera and/or species of potentially toxic algae (Pseudo-nitzschia sp., Alexandrium taylori, Prorocentrum micans, Skeletonema sp.), mostly in summer. Complessively, the phytoplankton biomass was always higher in marine site than in the fluvial site. The results were also processed considering the context of the chemical-physical parameters (such as temperature, $\mathrm{pH}$, salinity, nutrients). The high concentration of the nutrients $\mathrm{N}$ and $\mathrm{P}$ in such periods indicated a state of meso-eutrophic waters both in the proximity of river site as well as in the marine zone. The data represent the first contribution to the knowledge of the phytoplankton structure in this area, which results in a very variable environment with a high recovery capacity.
\end{abstract}

Keywords: Phytoplankton; Transitional Area; Lake of Tarsia; River Crati; Trophic State; Ionian Sea

\section{Introduction}

The study of phytoplankton derives from the importance that this plays as a major primary producer in aquatic environment. In fact, the phytoplankton is at the base of the food chain and it allows the livelihood of entire biological community of the ecosystem to which it belongs. Furthermore, the phytoplankton is one of the most important structural components, upon which scientific attention focuses when a management plan or an assessment of ecosystem health is required [1]. Aquatic environments are subject to high temporal variability, with frequent reorganization of the relative abundance and species composition of phytoplankton as a result of the interactions between physical, chemical and biological variables [2]. The study of changes in phytoplankton densities, biomass, species composition and primary production is essential to define the quality of marine and coastal waters, which are often altered by excessive urbanization and human activities, such as tourism, agriculture, aquaculture, etc. [3]. Over the last centuries, different direct and indirect human activities have modified the loads and fluxes of nutrients and sediments in surface waters, ground waters and through the hydrographic system towards the marine coastal ecosystem [4]. So, the knowledge of the different phytoplankton communities is critical to establish both the tropic structure and the biodiversity of ecosystem. Regarding the phytoplankton community of the Calabria water (both marine and fresh water), the literature data are very poor and fragmentary, and, as regards the transition zones, they are totally absent. In this study we performed a first approach to define the general features of the phytoplankton communities and their dynamics in a transitional environment of the Calabria coast. The mouths of large rivers are special envi- 
ronments, where the transition between land and sea and freshwater mixing with salted ones occurs, creating a mosaic of different habitats (reedbeds, ponds, lagoons, sandy islands, sandbars, flooded forests) of high natural interest. These habitats are highly sensitive ecosystems, with an ecology that depends strongly on both freshwater inputs and seawater exchanges; they are also under considerable natural stress because of the great variability in a large number of environmental factors, such as temperature, salinity and nutrients that mostly influence the phytoplankton composition and dynamics [5]. The phytoplankton variability is a primary driver of the chemical and biological dynamics of the coastal zone because it directly affects the water quality, the biogeochemical cycling of reactive elements and the food supply of consumer organisms [6]. Therefore, the data provided by monitoring phytoplankton are very useful indicators of environmental quality [7]. In this perspective, we performed a preliminary study on the composition and abundance of the phytoplankton communities and the trophic state of two sites near the mouth of the river Crati (Northern Ionian Sea). The analysis involved the identification of phytoplankton populations living at the mouth of the river Crati in two different seasonal periods (summer and autumn 2012). The results showed that the structure of the phytoplankton communities reflects the great variability of the examined environment, especially in relation to the river discharge, in turn, related to meteorological events.

\section{Material and Methods}

\subsection{Study-Area}

The selected area is placed in the Regional Natural Riserve "Lake of Tarsia-Mouth of river Crati", which includes several wetlands located along the river Crati. The establishment of the Regional Natural Reserves Lake of Tarsia-Mouth of the Crati is a site included in the Rasmar Convention and it is an Important Bird Area and a Site of Community Importance; the same Reserve aims to protect biodiversity and to implement specific projects improving the environmental quality of territory. The Natural Reserve extends over an area of approximately 600 hectares and it includes, in the North, the mouth of the river Crati, in the South the Tarsia Dam Reservoir; both the zones represent important wetland areas of great natural interest for the presence of different ecosystems and for a wide variety of plant and animal species. In this Regional Reserves we selected two sampling areas: the first named "fluvial site" located very close to the the mouth of river Crati $\left(39^{\circ} 43^{\prime} 26^{\prime \prime} \mathrm{N}, 16^{\circ} 31^{\prime} 48^{\prime \prime} \mathrm{E}\right)$; the second one named "marine site" located in the coastal zone, outside the mouth of the river and next to the accumulation of debris released by the delta of the river (Figure 1).

\subsection{Phytoplankton Sampling and Laboratory Analyses}

The phytoplankton sampling was carried out in June and October 2012 using nets of $20 \mu$ mesh; we sampled at a depth of $2 \mathrm{~m}$, along a transect about $1 \mathrm{~km}$ length. Water subsamples of $500 \mathrm{ml}$ were fixed in paraformaldehyde solution at $5 \%$ in dark glass bottles and they were transported to the laboratory, stored at $4^{\circ} \mathrm{C}$ and subsequently analyzed using the Utermöhl inverted microscope method [8]. After, each sample was thoroughly mixed and variable volumes of water $(5-10 \mathrm{ml})$, depending on phytoplankton density, were transferred into sedimentation chambers and allowed to settle. Cell counts were made with a Leica DML inverted microscope at magnification of $20 \times$ and species belonging to the major taxonomic groups were identified. Identification was predominantly based using the taxonomic keys [9,10]. The cell abundance (ind L-1) and the Shannon-Wiener diversity index (SWDIV) were calculated [11]. Water temperature $\left(\mathrm{T}^{\circ} \mathrm{C}\right)$, total dissolved salts (TDS ppt \%o), electrical conductivity (EC $\mu \mathrm{S}$ ), dissolved oxygen (DO \%) and $\mathrm{pH}$ were measured in situ with a multiparameter probe (MAR-3-Idromarambiente-Italy) at the superficial layers (30 cm depth). Water samples were also collected in dark bottles and stored in cold conditions for the laboratory analysis of ammonium $(\mathrm{N}-\mathrm{NH} 4)$, nitrite $\left(\mathrm{N}-\mathrm{NO}_{2}\right)$, nitrate $\left(\mathrm{N}-\mathrm{NO}_{3}\right)$ and total phosphorus (TP) according to Strickland and Parsons, 1972 [12]. In the same sampling areas the Shannon-Wiener diversity index (H') was applied in order to evaluate the species diversity [13].

\section{Results and Discussion}

\subsection{Environmental Context}

The epilimnetic temperature showed a seasonal dynamic, typical of Northern Ionian Sea, with minima in winter and maxima in summer. In both the sampling sites, the maximum value was detected in July, with a slight shift

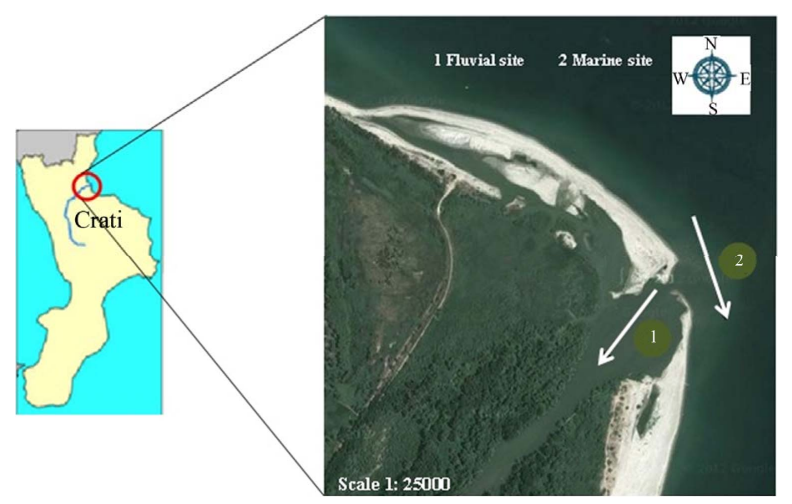

Figure 1. Map of mouth of the river Crati in the Natural Reserve "Lake of Tarsia-Mouth of river Crati"-Northern Ionian Sea, Calabria-Italy. Sampling sites: fluvial site (1); marine site (2). 
between the two sites: $\max 28.6^{\circ} \mathrm{C}$ in the marine site on July 18 th and $\max 28.1^{\circ} \mathrm{C}$ in the fluvial one on July $31 \mathrm{st}$

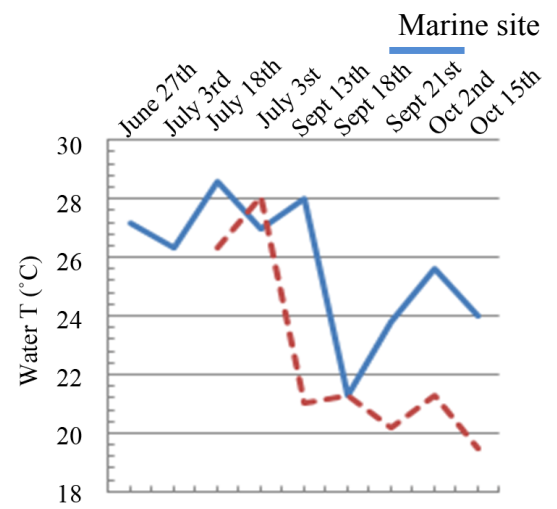

(a)

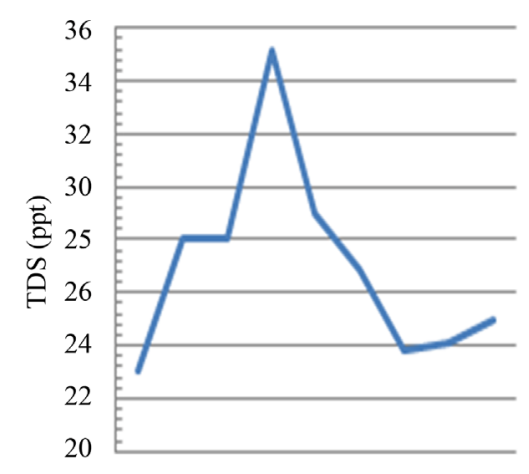

(c)

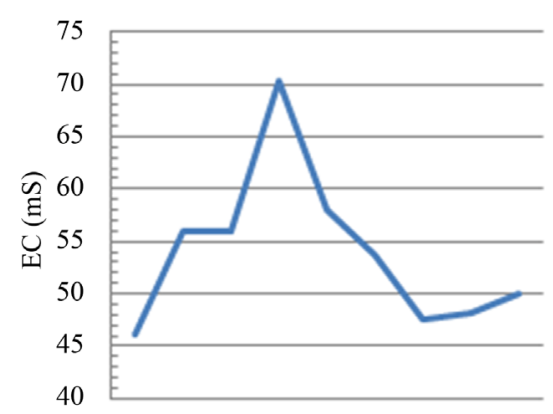

(e)

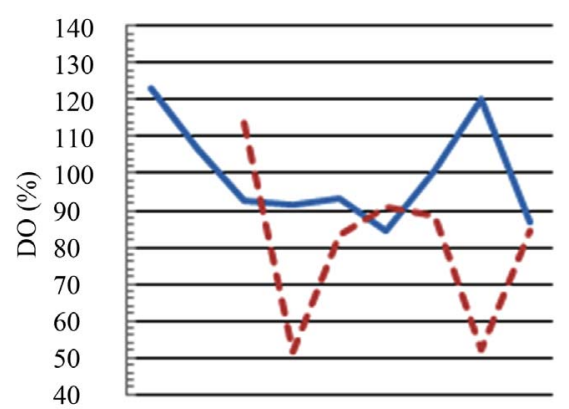

(g)
(Figure 2(a)). The observed variations in water temperature in the two analyzed areas depend mainly on the

Fluvial site

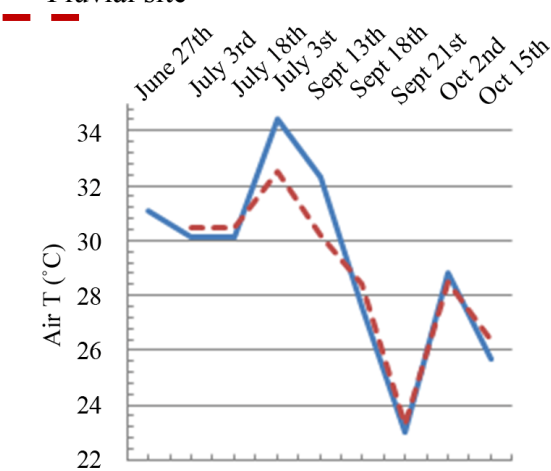

(b)

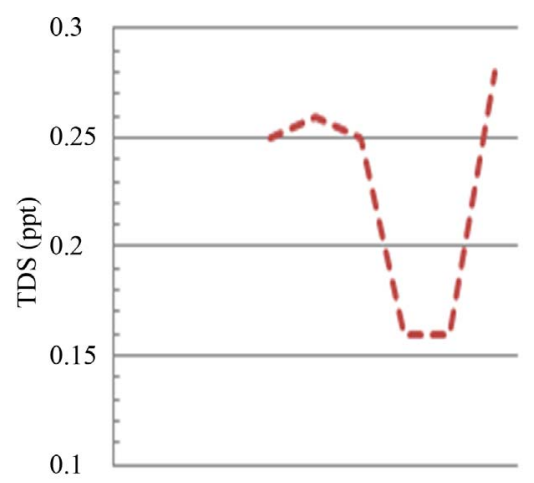

(d)

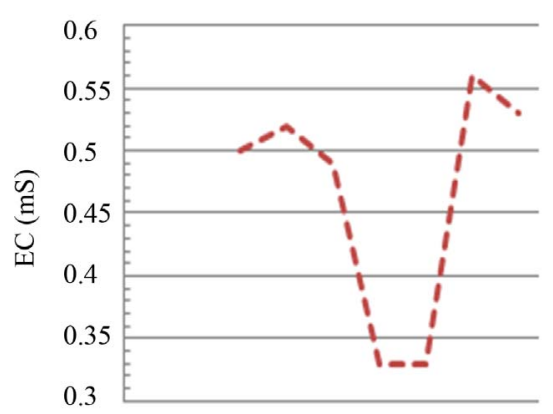

(f)

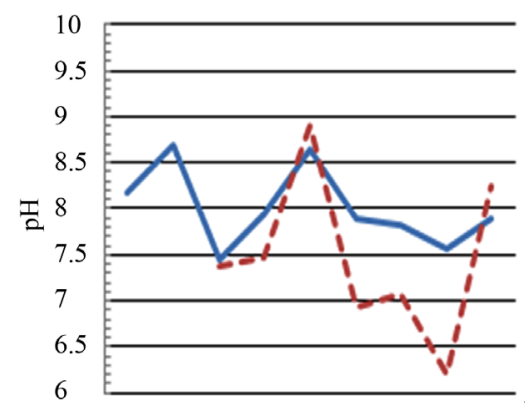

(h)

Figure 2. Temporal dynamic of the environmental parameters considered and their monthly variability in the sampling sites of Regional Natural Riserve "Lake of Tarsia-Mouth of River Crati” Epilimnetic temperature (a); air temperature (b); Salinity (c,d); electrical conductivity (e,f); Dissolved oxygen (g); pH (h). 
sampling period and they are strictly correlated to the atmospheric temperature (Figure 2(b)). The decrease and increase in water temperature depend also on the climatic conditions and the specific characteristics of water environment such as turbidity, wind force, plant cover affected these values [14].

The salinity values, related to the quantity of dissolved salts in the two sampling areas, respectively fluvial site vs marine site, show a ratio of 1:100 (Figures 2(c) and (d)). In particular, there are abrupt falls in salinity of marine site between July and September (from 35\% to $23 \%$ ), probably caused by strong rainfall and the biggest river flow (Figure 2(d)); in the fluvial site the abrupt falls were detected between September 13th and 18th (from $0.25 \%$ to $0.16 \%$ ) and between September 21 st and October 2 nd (from $0.16 \%$ to $0.28 \%$ ), also in relation to higher rainfalls (Figure 2(d)).

The electrical conductivity values are found in the same trend of the salinity in the both sampling areas because of the close correlation between these two parameters (Figures 2(e) and (f)). However, in this case, the values of electrical conductivity in the marine site show a ratio of 1:150 than the river site (Figure 2(e)). Several factors influence the conductivity including temperature, ionic mobility and ionic valences. In turn, conductivity provides a rapid mean of obtaining approximate knowledge of total dissolved salts concentration and salinity of water sample [14].

The dissolved oxygen data (expressed as \% of saturation) showed high values of $123 \%$ and $120 \%$ in the marine site (respectively in June and October 2012) and critical values of $51.4 \%$ and $52.3 \%$ in the fluvial site (respectively in July and October 2012) (Figure 2(g)). The dissolved oxygen is a parameter correlated to trophic status; values close to $100 \%$ saturation are optimal conditions, lower values indicate worst environmental quality until reaching zero for anoxia conditions; even higher values of $150 \%$ indicate critical conditions. The increase in dissolved oxygen levels might be the result of runoffs accounted for by autumn rains. At last, dissolved oxygen thus shows inverse relationship with water temperature (Figure 2(g)). As far as the $\mathrm{pH}$, it constitutes an impor- tant factor that determines the suitability of water for various purposes [15]. The temporal trend of $\mathrm{pH}$ in the sampling sites showed the greatest variations in the fluvial site (max 8.9 in July, min 6.2 in October) probably due to the instability of the river flow which can also vary in the dissolving organic material; more pronounced changes ( 7.45 to 8.65 ) were observed between June and July in marine area (Figure 2(h)), while $\mathrm{pH}$ maintained more stable (around 7.5 on average) during the period from September to October 2012 (Figure 2(h)).

The concentration of total azote (TN) and total phosphorous (TP) have been analyzed in four field sampling (Table 1) and compared with the reference values for trophic state of the water [16]. The concentrations of $\mathrm{N}$ (as ammonium, nitrites and nitrates) and the total $\mathrm{P}$, show variable values depending on the sampling period (Table 1). The hydrochemical data showed a great variability of the examined environment: in fact, we observed periods in which the values are significantly higher than those of reference values and other periods in which the amount of nutrients are below the limit of detection (not detectednd in Table 1). Complessively the nutrient concentrations referred the study-area as high trophic state (Table 1). In particular, as far as ammonium $(\mathrm{N}-\mathrm{NH} 4+)$ is concerned, we detected rather high values in marine area $(3 \mathrm{mg} / 1$ from July to October) compared to the reference values for oligotrophic water $(<0.01 \mathrm{mg} / \mathrm{l})$; in the fluvial site concentration of N-NH4+ varied between $0.17-0.27 \mathrm{mg} / \mathrm{l}$, indicating probably a recent organic contamination (Table 1). As far as the nitrites $\left(\mathrm{N}-\mathrm{NO}_{2}\right)$ is concerned, there was a very high value $(35 \mathrm{mg} / \mathrm{l})$ in June in the fluvial site, while in the marine one there is a relatively high value only in the sample of October 2012 (3.7 $\mathrm{mg} / \mathrm{l})$ compared to the reference values for oligotrophic water $(<1 \mathrm{mg} / \mathrm{l})$ indicating a high trophic level (Table 1). The concentrations of nitrates $\left(\mathrm{N}-\mathrm{NO}_{3}\right)$ showed a very high variability with values below the limit of detection in some periods and with very high values in other ones (Table 1). In particular, in the marine area, in the sampling of October, a value of $13.9 \mathrm{mg} / \mathrm{l}$ was found compared to $33.2 \mathrm{mg} / \mathrm{l}$ founded in the fluvial site, probably indicating a source of organic pollution.

Table 1. Nutrients values (mg/l) recorded in the two sampling areas (marine site vs fluvial one) during the seasonal periods (nd: not detected value).

\begin{tabular}{|c|c|c|c|c|c|c|c|c|}
\hline \multirow[t]{2}{*}{ Date } & \multicolumn{2}{|c|}{$\mathrm{NH}^{4+} \mathrm{mg} / \mathrm{l}$} & \multicolumn{2}{|c|}{ Nitrites $\left(\mathrm{N}-\mathrm{NO}_{2}\right) \mathrm{mg} / \mathrm{l}$} & \multicolumn{2}{|c|}{ Nitrates $\left(\mathrm{N}-\mathrm{NO}_{3}\right) \mathrm{mg} / 1$} & \multicolumn{2}{|c|}{ Total P (TP) mg/l } \\
\hline & Marine site & Fluvial site & Marine site & Fluvial site & Marine site & Fluvial site & Marine site & Fluvial site \\
\hline June 27 & nd & nd & nd & 35 & nd & nd & nd & 0.08 \\
\hline Sept 13 & 3 & 0.26 & nd & 8 & nd & nd & 0.12 & 0.07 \\
\hline Oct 02 & 3 & 0.17 & 3.7 & nd & 13.9 & nd & 0.1 & 2.27 \\
\hline Oct 15 & 3 & 0.27 & nd & nd & nd & 33.2 & 0.04 & 0.11 \\
\hline
\end{tabular}


Complessively, the variations in the total $\mathrm{N}$ detected in the study areas, may be mainly due to the atmosphere, surface runoff, sewage discharges, agricultural fertilizers and organic wastes. The highest recorded values may be due to the increased phytoplankton excretion, oxidation of ammonia and the reduction of nitrate and also by the recycling of nitrogen and bacterial decomposition of planktonic detritus which are present in the environment [17]. Finally, high concentration of total phosphorus (TP) $(2.27 \mathrm{mg} / \mathrm{l})$ was observed in the fluvial site in October, compared to the reference values for oligotrophic water $(<0.02 \mathrm{mg} / \mathrm{l})$ indicating a high trophic level (Table 1) (reference value for high eutrophy is $>0.2 \mathrm{mg} / \mathrm{L}$ ).

\subsection{Phytoplankton Composition, Abundance and Diversity}

A total of 38 phytoplanktonic genera/species, belonging to three taxonomic groups (Dinophyceae, Bacillariophyceae and Chloropyceae), were recorded during the survey (Table 2). In this study 9 genera/species of Dinophyceae, 22 genera/species Bacillariophyceae (Diatoms) and 2 genera/species of Chloropyceae (green algae) were identified. In particular, 31 phytoplanktonic genera were recorded in the samples of the marine area and 24 genera in the fluvial one; furthermore 6 genera of Dinophyceae and 4 genera of Bacillariophyceae were exclusive of the marine area (Table 2). The most diverse and abundant group was Bacillariophyceae, which contributed $86 \%$ $91 \%$ of the total assemblage of phytoplankton in marine area, and $94 \%$ - 99\% of the total assemblage of phytoplankton in fluvial one, respectively in both seasonal sampling periods (June and October 2012) (Figures 3(a)(d)). As far as the Bacillariophyceae, in the sampling of June Pseudo-Nitzschia sp., Leptocilindrus sp., and Skeletonema $s p$. were the most dominant diatoms genera in the marine zone while the genus Leptocilindrus $s p$. and Lytodesmum danicus were the most dominant in the fluvial area; in the sampling of October, the diatoms genera Leptocilindrus sp., PseudoNitzschia sp., and Lythodesmum danicus decreased drastically in both analyzed areas. In the same sampling period, the diatoms Haslea wawrikae, Nitzschia longissima, Pseudo-Nitzschia sp., Lythodesmum danicus, Hemiaulus hauckii, Proboscia alata, Asterionellopsis sp., Guinardia flaccida, Talassiotrix sp., Tricotoxon sp. and Amphora sp. were exclusive species of the marine area, even if at low-density; while, Fragilariopsis sp. and Manguinea sp. and Fragilaria striatula appeared in both analyzed areas and, among these $F$. striatula was the most dominant, especially in marine sample (Table 2). The second most dominant taxonomic group was the Dinophyceae which contributed 12\% - 8\% of the total identified phytoplankton communities in marine samples and $2 \%-1 \%$ of the total phytoplankton communities in fluvial ones, respectively in the two
Table 2. Floristic list of genera and/or species detected in the sampling periods in the two study-areas (marine site vs fluvial one). Legend: $+=$ almost absent; $++=$ little abundant; $+++=$ abundant; $++++=$ very abundant; $\left(^{*}\right)=$ genera that include potentially toxic species.

\begin{tabular}{|c|c|c|c|c|}
\hline & \multicolumn{2}{|c|}{ June 27} & \multicolumn{2}{|c|}{ Oct 02} \\
\hline & $\begin{array}{c}\text { Marine } \\
\text { site }\end{array}$ & $\begin{array}{c}\text { Fluvial } \\
\text { site }\end{array}$ & $\begin{array}{c}\text { Marine } \\
\text { site }\end{array}$ & $\begin{array}{c}\text { Fluvial } \\
\text { site }\end{array}$ \\
\hline \multicolumn{5}{|l|}{ Genera/Species } \\
\hline \multicolumn{5}{|l|}{ Dinophyceae } \\
\hline Alexandrium taylori (*) & +++ & - & - & - \\
\hline Ceratium furca & + & - & ++ & + \\
\hline Ceratiumtrichoceros & - & - & + & - \\
\hline Ceratocoryshorrida & + & - & - & - \\
\hline Dinophisis sp. & + & - & - & - \\
\hline Mesoporos sp. & + & - & - & - \\
\hline Prorocentrum micans & ++ & + & - & - \\
\hline Protoceratium sp. & + & - & - & - \\
\hline Protoperidinium sp. & + & - & - & - \\
\hline \multicolumn{5}{|l|}{ Bacillariophyceae } \\
\hline Amphora sp. & - & - & + & - \\
\hline Asterionellopsis sp. & + & + & - & - \\
\hline Fragilaria striatula & + & + & +++ & + \\
\hline Fragilariopsis sp. & - & - & + & + \\
\hline Guinardia flaccida & + & + & + & - \\
\hline Gyrosigma sp. & + & + & + & + \\
\hline Haslea wawrikae & ++ & ++ & + & - \\
\hline Hemialus hauckii & + & + & + & - \\
\hline Leptocilindrus sp. & ++++ & +++ & + & + \\
\hline Licmophora gracilis & - & + & - & - \\
\hline Lythodesmum danicus & +++ & +++ & + & - \\
\hline Manguinea sp. & - & - & + & + \\
\hline Navicula sp. & + & + & ++ & ++ \\
\hline Nitzschia longissima & ++ & + & + & - \\
\hline Plagiotropis sp. & + & + & - & + \\
\hline Proboscia alata & ++ & + & + & - \\
\hline Pseudo-Nitzschiasp. (*) & ++++ & + & + & - \\
\hline Rhizosolenia sp. & + & + & - & - \\
\hline Sinedropsis sp. & + & + & + & + \\
\hline Skeletonemasp. (*) & ++ & + & - & - \\
\hline Thalassiosira sp. & - & + & - & - \\
\hline Thalassiotrix sp. & - & - & + & - \\
\hline \multicolumn{5}{|l|}{ Chlorophyceae } \\
\hline Pediastrum sp. & + & + & + & - \\
\hline Scenedesmus quadricauda & + & + & + & - \\
\hline
\end{tabular}




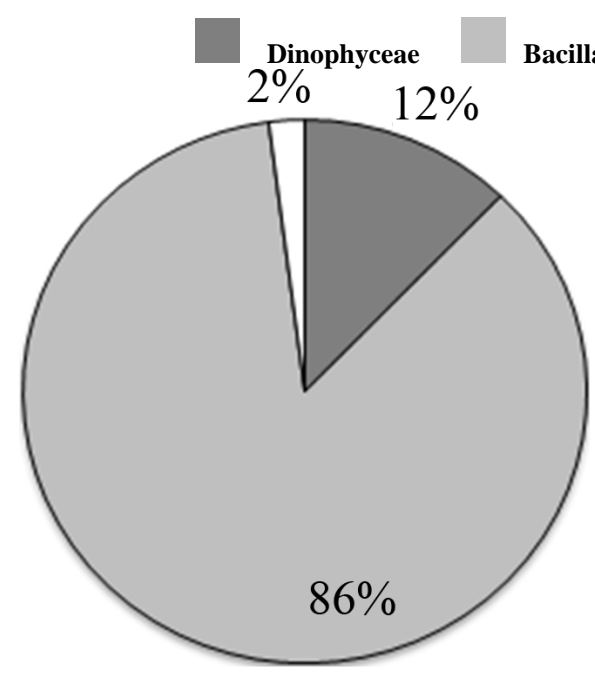

(a)

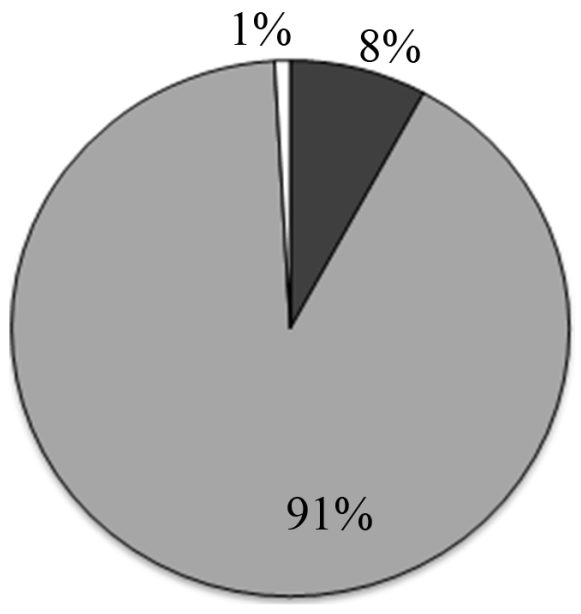

(c)

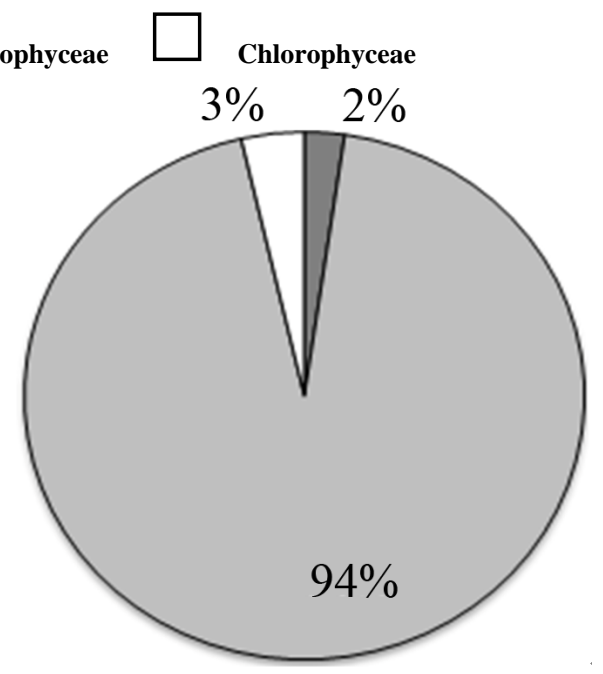

(b)

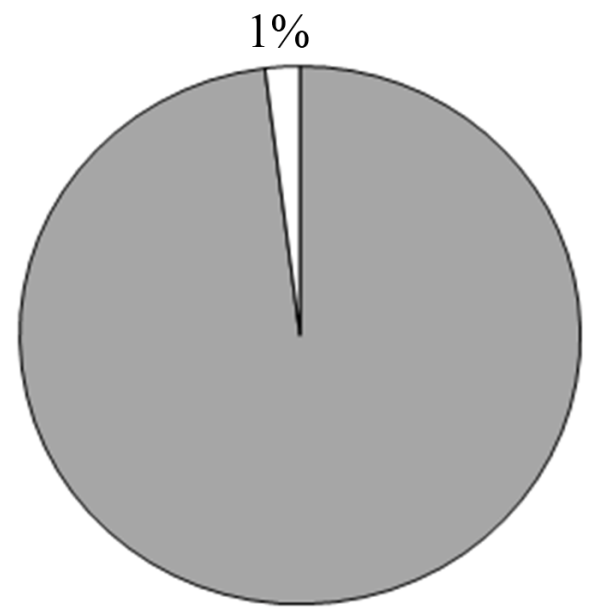

(d)

Figure 3. Abundance (\%) of phytoplankton communities in the sampling sites at June 2012 marine site (a) and fluvial site (b); at October 2012 marine site (c) and fluvial site (d).

seasonal sampling periods (June and October 2012) (Figures 3(a)-(d)). As far as the Dinophyceae are concerned, Prorocentrum micans was identified in the two studied areas in June, while the genera Dinophisis sp. Protoperidinium sp., Mesoporos sp., Protoceratium sp. and the species Ceratocory horrida, Alexandrium taylori were exclusive of the marine area (Table 2). In the sampling of October, a seasonal variation in species composition was observed: all the genera, identified in the marine area in June, were absent in October, except for Ceratium furca, identified in the both sampling areas; furthermore, Ceratium thricoceros was observed for the first time only in the marine area and Alexandrium taylori, a potentially toxic species, disappeared completely in October (Table 2). The Chloropyceae were the under-represented group which covered only $2 \%-1 \%$ of the total assemblage of phytoplankton in the marine site and 3\%- $0 \%$ in the fluvial one, respectively in the two seasonal sampling periods (June and October 2012) (Figures 3(a)-(d)). Scenedesmus quadricauda and Pediastrum sp. were the only detected Chloropyceae in both study-areas in June, while they were no longer found in the mouth area in the sampling of October (Table 2). The total phytoplankton biomass, expressed as total densities (cell $/ \mathrm{ml}$ ), is always higher in marine area vs fluvial area in both sampling period (Figures 4(a) and (b)); a significant reduction in the phytoplankton density of the fluvial area was observed in October (Figure 4(b)). As far as the dominant species, in the sampling of June, in the marine area, the diatoms Pseudo-Nitzschia sp. and Leptocilindrus sp. showed a density of $10,926 \mathrm{cell} / \mathrm{ml}$ and $8849 \mathrm{cell} / \mathrm{ml}$ respectively, representing $33.6 \%$ and $27.2 \%$ of the whole Diatoms group (Table 3); on the contrary, the genera Sinedropsis sp., Plagiotropis sp. and Rhizosolenia sp. show the lowest density $(0.1 \%)$ (Table 3$)$. In the same sampling period, in the fluvial area, the higher density was supported 


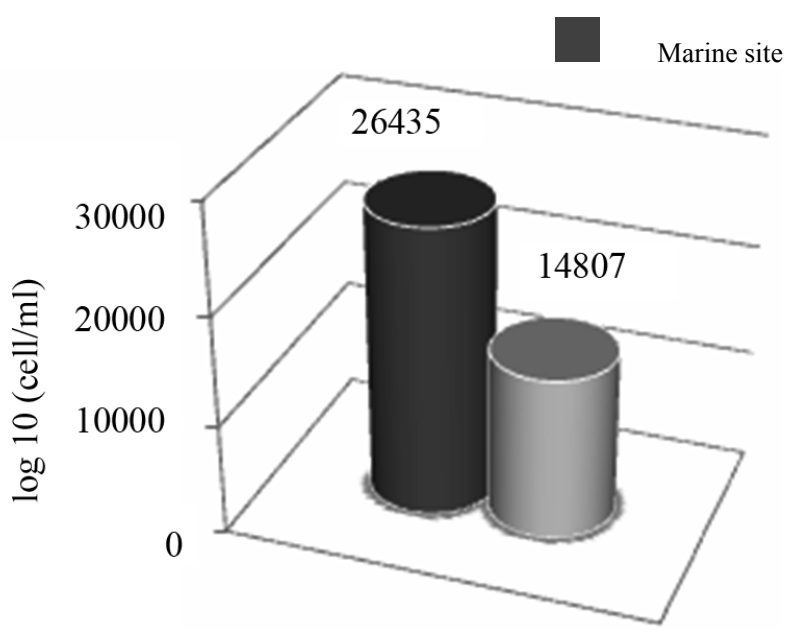

(a)

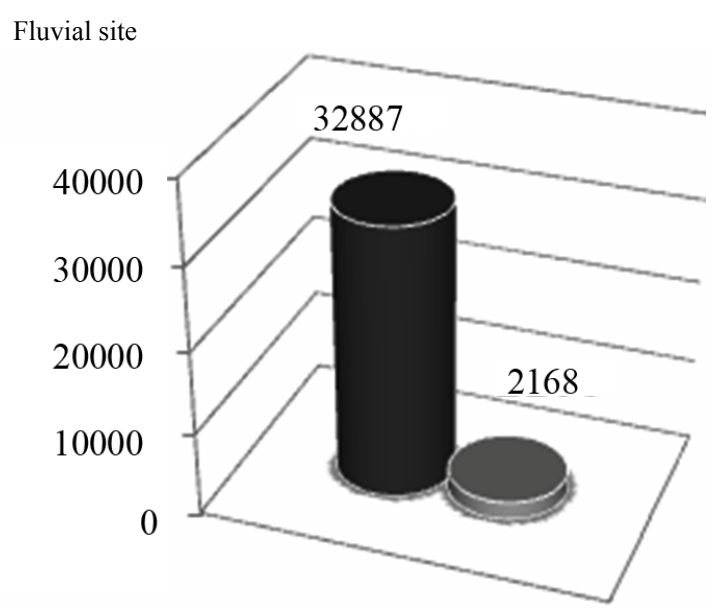

(b)

Figure 4. Total phytoplankton biomass (cell/ml) in the sampling sites at June 2012 (a) and October 2012 (b).

by the diatom Leptocilindrus sp., although with a lower density respect to the marine area ( $5660 \mathrm{cell} / \mathrm{ml}$ vs 8849 cell $/ \mathrm{ml}$ ); also Pseudo-Nitzschia sp. density was greatly reduced in the fluvial area $(170 \mathrm{cell} / \mathrm{ml}$ vs $10926 \mathrm{cell} / \mathrm{ml})$ (Table 3). The lowest density was achieved by genera Rhizosolenia sp., Gyrosigma sp., Sinedropsis sp. and the species Fragilaria striatula (Table 3). Regarding Dinophyceae, the dominant species was Alexandrium taylori (2077 cell $/ \mathrm{ml}$ ) representing $64 \%$ of the total number of Dinophyceae (Table 3); Dinophisis sp. and Ceratium furca showed the lowest density (24 cell/ml) (Table 3). Complessively, in the sampling of June, the Dinophyceae communities were very different in the two sampling areas: all genera/species identified in sea area, were absent in the fluvial one, except for Prorocentrum micans, assesed at a reduced density than half compared to marine sample $(340 \mathrm{cell} / \mathrm{ml}$ vs $617 \mathrm{cell} / \mathrm{ml}$ ) (Table 3). In October, the density of different phytoplankton genera decreased noticeably in the samples of marine area, and Fragilaria striatula showed the highest density, representing the $69.2 \%$ of total number of Diatoms $(20,694$ cell $/ \mathrm{ml}$ ) (Table 3); it was followed by the genera Navicula sp. (2292 cell/ $/ \mathrm{ml})$ and Sinedropsis sp. $(11,179 \mathrm{cell} / \mathrm{ml})$ (Table 3). In the samples of mouth, many genera/species such as Nitzschia longissima, Pseudo-Nitzschia sp. and Guinardia flaccida were absent; the higher density were achieved by Navicula sp. $(840 \mathrm{cell} / \mathrm{ml} ; 39 \%$ of the total number of Diatoms); Fragilariopsis sp. and Fragilaria striatula (22\% and $16 \%$ respectively) (Table 3). As far as the Dinophyceae, in the marine samples, all genera/ species detected in June disappeared in October, except for Ceratium furca $(2448 \mathrm{cell} / \mathrm{ml})$ which represented 94\% of the total number of Dinophyceae; C. trichoceros wasn't prominent (Table 3). In the samples of mouth Prorocentrum micans disappeared and Ceratium furca was the only present species $(22 \mathrm{cell} / \mathrm{ml}$ ) (Table 3$)$. The
Shannon-Wiener diversity index (H') based on the relative species abundance, showed the higher value (2.1) in the marine site on June 2012, when the Diatoms reached a high variety in species; the lowest value (1.5) was in the fluvial area on October when 10 genera/species of Diatoms disappear. Complessively, comparing the differences between ecological communities in marine site vs fluvial one, the diversity was relatively high in the marine area which indicates good environmental conditions and a moderate trophy of waters.

\section{Conclusion}

The primary objective of this study was to investigate the phytoplankton communities in a coastal site of the Natural Reserve "Lake of Tarsia-Mouth of the river Crati". Phytoplankton is a useful indicator of water quality, because these communities develop and exist under the influence of environmental biological and physical factors $[18,19]$. Moreover, the Natural Reserve "Lake of Tarsia-Mouth of the river Crati" is a very interesting transitional coastal ecosystem and, as deltas, estuaries and lagoons, is characterized by important environmental gradients such as water replacement, salinity, turbidity, structure of sediments and nutrient loading [20,21]. This study was carried out in two seasonal periods (June-October 2012) and in two different sites (fluvial vs marine area). The hydrochemical data showed that studied areas were relatively eutrophic with high concentrations of total $\mathrm{N}$ and total $\mathrm{P}$ in both sampling sites. However, the two examined sites showed a very sudden change in nutrient concentrations and availability, depending on the river regime and meteoric events. This probably induces the fast changes in phytoplankton composition that we observed. Phytoplankton communities are in fact, the first to suffer the effect and/or to draw any benefits from 
Table 3. Taxa identified in two study-areas (marine site vs fluvial one) and their average abundance (cell/ml and \%) during the sampling periods.

\begin{tabular}{|c|c|c|c|c|c|c|c|c|}
\hline & \multicolumn{4}{|c|}{ June 27} & \multicolumn{4}{|c|}{ Oct 02} \\
\hline & \multicolumn{2}{|c|}{ Marine site } & \multicolumn{2}{|c|}{ Fluvial site } & \multicolumn{2}{|c|}{ Marine site } & \multicolumn{2}{|c|}{ Fluvial site } \\
\hline Genera/Species & \multicolumn{8}{|c|}{ Abundance } \\
\hline Dinophyceae & cell $/ \mathrm{ml}$ & $\%$ & cell $/ \mathrm{ml}$ & $\%$ & cell/ml & $\%$ & cell/ml & $\%$ \\
\hline Alexandrium taylori & 2077 & 66.0 & 0 & 0.0 & 0 & 0.0 & 0 & 0.0 \\
\hline Ceratium furca & 25 & 0.8 & 0 & 0.0 & 2448 & 94.0 & 22 & 100.0 \\
\hline Ceratium trichoceros & 0 & 0.0 & 0 & 0.0 & 149 & 5.7 & 0 & 0.0 \\
\hline Ceratocorys horrida & 267 & 8.5 & 0 & 0.0 & 0 & 0.0 & 0 & 0.0 \\
\hline Dinophisis sp. & 25 & 0.8 & 0 & 0.0 & 0 & 0.0 & 0 & 0.0 \\
\hline Mesoporos sp. & 0 & 0.0 & 0 & 0.0 & 0 & 0.0 & 0 & 0.0 \\
\hline Prorocentrum micans & 617 & 19.0 & 341 & 100.0 & 0 & 0.0 & 0 & 0.0 \\
\hline Protoceratium sp. & 0 & 0.0 & 0 & 0.0 & 0 & 0.0 & 0 & 0.0 \\
\hline Protoperidinium sp. & 123 & 3.9 & 0 & 0.0 & 0 & 0.0 & 0 & 0.0 \\
\hline \multicolumn{9}{|l|}{ Bacillariophyceae } \\
\hline Amphora sp. & 0 & 0.0 & 0 & 0.0 & 149 & 0.5 & 0 & 0.0 \\
\hline Asterionellopsis sp. & 222 & 0.7 & 296 & 2.1 & 66 & 0.2 & 0 & 0.0 \\
\hline Fragilaria striatula & 267 & 0.8 & 22 & 0.2 & 20694 & 69.2 & 346 & 16.0 \\
\hline Fragilariopsis sp. & 0 & 0.0 & 0 & 0.0 & 445 & 1.5 & 469 & 22.0 \\
\hline Guinardia flaccida & 197 & 0.6 & 123 & 0.9 & 66 & 0.2 & 0 & 0.0 \\
\hline Gyrosigma sp. & 49 & 0.2 & 22 & 0.2 & 594 & 2.0 & 49 & 2.3 \\
\hline Haslea wawrikae & 2373 & 7.3 & 741 & 5.3 & 1037 & 3.5 & 0 & 0.0 \\
\hline Hemialus hauckii & 494 & 1.5 & 123 & 0.9 & 289 & 10 & 0 & 0.0 \\
\hline Leptocilindrus sp. & 8849 & 27.2 & 5660 & 40.7 & 890 & 3.0 & 22 & 10.0 \\
\hline Licmophora gracilis & 0 & 0.0 & 49 & 0.4 & 0 & 0.0 & 0 & 0.0 \\
\hline Lythodesmum danicus & 3288 & 10 & 4796 & 34.5 & 133 & 0.4 & 0 & 0.0 \\
\hline Manguinea sp. & 0 & 0.0 & 0 & 0.0 & 594 & 2.0 & 123 & 5.7 \\
\hline Navicula sp. & 118 & 0.4 & 296 & 2.1 & 2292 & 7.7 & 840 & 39.0 \\
\hline Nitzschia longissima & 2893 & 8.9 & 689 & 5.0 & 66 & 0.2 & 0 & 0.0 \\
\hline Plagiotropis sp. & 24 & 0.1 & 49 & 0.4 & 0 & 0.0 & 22 & 10.0 \\
\hline Proboscia alata & 840 & 2.6 & 667 & 4.8 & 890 & 30 & 0 & 0.0 \\
\hline Pseudo-Nitzschia sp. & 10926 & 33.6 & 170 & 1.2 & 222 & 0.7 & 0 & 0.0 \\
\hline Rhizosolenia sp. & 24 & 0.1 & 22 & 0.2 & 0 & 0.0 & 0 & 0.0 \\
\hline Sinedropsis sp. & 24 & 0.1 & 22 & 0.2 & 1179 & 3.9 & 272 & 12.7 \\
\hline Skeletonema sp. & 1903 & 5.9 & 49 & 0.4 & 0 & 0.0 & 0 & 0.0 \\
\hline Thalassiosira sp. & 0 & 0.0 & 123 & 0.9 & 0 & 0.0 & 0 & 0.0 \\
\hline Thalassiotrix sp. & 0 & 0.0 & 0 & 0.0 & 222 & 0.7 & 0 & 0.0 \\
\hline \multicolumn{9}{|l|}{ Chlorophyceae } \\
\hline Scenedesmus quadricauda & 24 & 4.4 & 314 & 58.6 & 149 & 50.0 & 0 & 0.0 \\
\hline Pediastrum sp. & 519 & 95.6 & 222 & 41.4 & 149 & 50.0 & 0 & 0.0 \\
\hline
\end{tabular}


periods characterized by high presence of nutrients; the high trophy, detected especially in some periods, feeds phytoplankton growth with likely positive effects even for upper trophic rings [22,23]. Moreover, it is necessary to highlight that phytoplankton biodiversity and dynamoics in transitional waters are controlled by different factors, such as flushing rate, residence time, depth, salinity, light and nutrient concentrations; the relevance of each of these factors to the dynamics of phytoplankton guilds is modulated by specific geo- and hydrodynamic properties of each singular transitional system, which determine the differentiation of phytoplankton assemblages [24].

Climatic variations affect phytoplankton directly by eliciting physiological and adaptive responses, and indirectly by inducing hydrological and biological changes, which influence both bottom-up and top-down processes involving phytoplankton variability [25]. Recent studies have shown that long-term climate variability may also induce changes in the magnitudes and positions of phytoplankton blooms, and in their composition and phenollogy. The associated consequences may be propagated to higher trophic levels [26].

In our study, the estimated density has been used to describe the contribution of each taxon in algal community structure. The phytoplankton communities are dominated by Diatoms, pleased by reduced alkalinity and high nutrient content [27]; they are also indicators of good water quality. In particular, the pennate diatoms bloomed especially in summer in the marine area, when the fluvial input (mainly N-NO2) acts as feeding for the phytoplankton growth. The major phytoplanktonic biodiversity detected at June was coincident with the major variability in all the environmental parameters considered, particularly in nutrients and salinity. A large number of Diatoms were simultaneously present with the dominance of Pseudonitzschia sp. in marine area; in October, when the strong rainfall began, the phytoplankton composition become less variable, with the completely dominant specie Fragilaria striatula. Qualitative analyses indicated also the presence of genera that include potentially toxic species, such as Alexandrium taylori, Skeletonema sp., and Pseudo-Nitzschia sp., in both sampling sites, with a higher percentage in June. Subsequent studies will provide a more detailed picture and clear seasonal dynamics of phytoplankton communities and its relationship with the trophic chain. The intrinsic complexity of the phytoplankton system in transitional environments makes the analysis of long-term series particularly useful, allowing exploitable reconstructions of seasonal cycles of phytoplankton [28]. So, further sampling plans and monitoring programs could allow detecting any early blooms of these toxic algal species in the studied area. Nevertheless, this study may also serve as a baseline to investigate this transitional ecosystem that, in spite of this extreme variability in the nutrient input from local farmers and urban discharges to the river Crati, is able to maintain a good trophic status and a discrete biodiversity.

\section{Acknowledgements}

The authors would like to thank the Managing Authority of the Regional Natural Reserves "Lake of Tarsia and Mouth of river Crati-Friends of the Earth Italy" for their financial and technical support.

\section{REFERENCES}

[1] Y. Monbet, "Control of Phytoplankton Biomass in Estuaries: A Comparative Analysis of Microtidal and Macrotidal Estuaries," Estuaries, Vol. 15, No. 4, 1992, pp. 563571. http://dx.doi.org/10.2307/1352398

[2] C. S. Reynolds, "Temporal Scales of Variability in Pelagic Environments and Response of Phytoplankton," Freshwater Biology, Vol. 23, No. 1, 1990, pp. 25-53. http://dx.doi.org/10.1111/j.1365-2427.1990.tb00252.x

[3] W. D. Taylor, E. Kebede and Z. Gebre-Mariam, "Primary and Secondary Production in the Pelagic Zone of Ethiopian Rift Valley Lakes," In: C. Tudorancea and W. D. Taylor, Eds., Ethiopian Rift Valley Lakes, Backhuys Publishers, Leiden, 2002, pp. 95-108.

[4] A. M. Mercury, L. Sadori and C. Blasi Editorial, "Archaeobotany for Cultural Landscape and Human Impact Reconstructions," Plant Biosystem, Vol. 144, No. 4, 2010, pp. $860-864$

http://dx.doi.org/10.1080/11263504.2010.514137

[5] H. Postma, "Future of Research in Coastal Lagoons," In: B. Kjefve, Ed., Coastal Lagoon Processes, Elsevier Oceanography Series, Vol. 60, 1994, pp. 553-561. http://dx.doi.org/10.1016/S0422-9894(08)70024-2

[6] J. E. Cloern and D. J. Jassby, "Patterns and Scales of Phytoplankton Variability in Estuarine-Coastal Ecosystems," Estuares and Coast, Vol. 33, No. 2, 2009, pp. 230-241. http://dx.doi.org/10.1007/s12237-009-9195-3

[7] A. Marchetto, B. M. Padedda, M. A. Mariani, A. G. Lugliè and N.Sechi, "A Numerical Index for Evaluating Phytoplankton Response to Changes in Nutrient Levels in Deep Mediterranean Reservoirs," Journal of Limnology, Vol. 68, No. 1, 2009, pp. 106-121. http://dx.doi.org/10.4081/jlimnol.2009.106

[8] H. Utermöhl, "Neue Wege in der Quantitativen Erfassung des Planktons. (Mit besondere Beriicksichtigung des U1traplanktons)," Verhandlungen des Internationalen Verein Limnologie, Vol. 5, 1931, pp. 567-596.

[9] M. Avancini, A. Cicero, I. Di Giordano, M. Innamorati and E. Magaletti, "Guide to Recognition of the Phytoplankton of the Italian Seas: Monitoring Program for Controlling the Coastal Marine Environment," In: T. Sertorio Zunini, Ed., Ministero dell'ambiente e Della Tutela del Territorio e del Mare-ICARAM, Vol. 1, Phytoplankton, Rome, 2006, p. 503.

[10] C. R. Tomas, "Identifying Marine Phytoplankton," Academic Press, New York, 1997. 
[11] C. E. Shannon and W. Weaver, "The Mathematical Theory of Communication," The University of Illinois Press, Urbana, 1949

[12] J. D. H. Strickland and T. R. Parsons, "A Practical Handbook of Seawater Analysis," Bull Fish Res Board Can, 1972, pp. 167.

[13] C. J. Krebs, "Ecology: The Experimental Analysis of Distribution and Abundance," In: H. I. Lectual Ed., New York, 1996.

[14] S. A. Mahmoud, "Evaluation of Toxicity of Some Pollutant on Histological and Biochemical Features of Orcachomis Niloticus in River Nile," Ph.D. Thesis, Zagazig University, Zagazig, 2002.

[15] M. V. Ahipathy and E. T. Puttaiah, "Ecological Characteristics of Vrishabhavathy River in Bangalore (India)," Environmental Geology, Vol. 49, No. 8, 2006, pp. 12171222. http://dx.doi.org/10.1007/s00254-005-0166-0

[16] F. Giovanardi and R. A. Vollenweider, "Trophic Conditions of Marine Coastal Waters: Experience in Applying the Trophic Index TRIX to Two Areas of the Adriatic and Tyrrhenian Seas," Journal of Limnology, Vol. 63, No. 2, 2004, pp. 199-218. http://dx.doi.org/10.4081/ilimnol.2004.199

[17] C. Govindasamy, L. Kannan and J. Azariah, "Seasonal Variation in Physico-chemical Properties and Primary Production in the Coastal Water Biotopes of Coromandel Coast (India)," Journal of Environmental Biology, Vol. $21,2000$.

[18] J. Cloern, "Our Evolving Conceptual Model of the Coastal Eutrophication Problem," Marine Ecology Progress Series, Vol. 210, 2001, pp. 223-228. http://dx.doi.org/10.3354/meps210223

[19] J. L. Pinckney, H. W. Pearl, E. Haugen and P. A. Tester, "Response of Phytoplankton and Pfiesteria-like-dinoflagellate Zoospores to Nutrient Enrichment in the Neuse River Estuary," Mar. Ecology Progress Series, Vol. 192, North Carolina, 2000, pp. 65-78.

[20] H. W. Paerl, L. M. Valdes-Weaver, A. R. Joyner and V. Winkelmann, "Phytoplankton Indicators of Ecological Change in the Eutrophying Pamlico Sound System," Ecological Applicators, Vol. 17, No. 5, 2007, pp. S88-S101.
[21] S. W. Nixon, "Coastal Marine Eutrophication: A Definition, Social Causes, and Future Concerns," Ophelia, Vol. 41, 1995, pp. 199-219.

[22] S. Pulina, B. M. Padedda, C. T. Satta, N. Sechi and A. Lugliè, "Long-term Phytoplankton Dynamics in a Mediterranean Eutrophic Lagoon (Cabras Lagoon, Italy)," Plant Biosystem, Vol. 146, No. S1, 2012, pp. 259-272. http://dx.doi.org/10.1080/11263504.2012.717545

[23] T. Wondmagegne, A. Wondie, M. Mingist and J. Vijverberg, "Seasonality in Abundance, Biomass and Production of the Phytoplankton of Welala and Shesher Wetlands, Lake Tana Sub-Basin (Ethiopia)," Journal of Water Resource and Protection, Vol. 4, 2012, pp. 877-884.

[24] M. R. Vadrucci, L. Sabetta, A. Fiocca, C. Mazziotti, C. Silvestri, M. Cabrini, et al., "Statistical Evaluation of Differences in Phytoplankton Richness and Abundance as Constrained by Environmental Drivers in Transitional Waters of the Mediterranean Basin," Aquatic Conservation: Marine and Freshwater Ecosystems, Vol. 18, No. S1, 2008, pp. 88-104. http://dx.doi.org/10.1002/aqc.951

[25] A. Zingone and H. O. Enevoldsen, "The Diversity of Harmful Algal Blooms: A Challenge for Science and Management," Ocean \& Coastal Management, Vol. 43, 2000, pp. 725-748.

http://dx.doi.org/10.1016/S0964-5691(00)00056-9

[26] A. B. Barbosa, R. B. Domingues and H. M. Galvão, "Environmental Forcing of Phytoplankton in a Mediterranean Estuary (Guadiana Estuary, South-Western Iberia): A Decadal Study of Anthropogenic and Climatic Influences," Estuaries and Coasts, Vol. 33, No. 2, 2010, pp. 324-341. http://dx.doi.org/10.1007/s12237-009-9200-x

[27] B. F. Cumming, S. E. Wilson, R. I. Hall and J. P. Smol, "Diatoms from British Columbia (Canada) Lakes and Their Relationship to Salinity, Nutrients and Other Limnological Variables, Bibliotheca Diatomologica," Berlin, Stuttgart, 1995, Vol. 31.

[28] J. E. Cloern and D. J. Jassby, "Patterns and Scales of Phytoplankton Variability in Estuarine-Coastal Ecosystems," Estuares and Coast, Vol. 33, No. 2, 2009, pp. 230-241. http://dx.doi.org/10.1007/s12237-009-9195-3 